\title{
The Effect of the Water Extracts of Digestive Medicinal Plants on the Shelf-life of Pork Patties
}

\author{
Kuk-Hwan Seol ${ }^{1}$, Hyun-Chul Seol ${ }^{2}$, Thirawong Prayad, Hyoun Wook Kim¹, Aera Jang ${ }^{1}$, \\ Jun-Sang Ham ${ }^{1}$, Mi-Hwa Oh${ }^{1}$, Dong-Hun $\mathrm{Kim}^{1}$, and Mooha Lee* \\ Department of Food and Animal Biotechnology, Research Institute for Agriculture and Life Science, \\ Seoul National University, Seoul 151-921, Korea \\ ${ }^{1}$ National Institute of Animal Science, Rural Development Administration, Suwon 441-706, Korea \\ ${ }^{2}$ Byucksan Oriental Medicine Clinic, Seoul 153-035, Korea
}

\begin{abstract}
This study was performed to examine the possibility of water extracts of several digestive medicinal plants (DMPEs), such as Amomum tasoko, Alpinia oxyphylla, Citrus unshiu, and Myristica fragrans, as a natural antioxidant. Total phenol contents of each extract were expressed as gallic acid equibalents (GAE) and those were significantly different among $A$. tasoko (39.87 $\pm 5.77 \mathrm{mg} \mathrm{GAE} / \mathrm{g})$, A. oxyphylla (30.28 $\pm 3.36 \mathrm{mg} \mathrm{GAE} / \mathrm{g})$, C. unshiu $(28.13 \pm 5.01 \mathrm{mg} \mathrm{GAE} / \mathrm{g})$ and M. fragrans $(6.36 \pm 0.30 \mathrm{mg} \mathrm{GAE} / \mathrm{g})(p<0.05)$, and extract of $A$. tasoko showed significantly higher antioxidative effect than butylated hydroxyanisole (BHA) on linoleic acid peroxidation at $72 \mathrm{~h}$ after incubation $(p<0.05)$. Addition of extracts in pork patties did not affect the $\mathrm{pH}$ value and total microbes during cold storage. However, thiobarbituric acid reative substances (TBARS) of treated patties were lower in dose dependant manner than that of control as storage period increased (except patties treated with C. unshiu extract), and patties treated with $0.5 \%$ A. tasoko extract showed no significant difference with patties treated with $0.5 \%$ BHA at day 7 .
\end{abstract}

Key words: digestive medicinal plant extracts, antioxidative effect, pork patty, shelf-life

\section{Introduction}

Lipid peroxidation not only produces rancid odours and flavours, but also decreases safety and nutritional quality by destruction of essential fatty acids and vitamins in foods during cooking, processing and storage. Lipid peroxidation causes aging, heart disease and carcinogenesis (Edwin, 1996). Oxidation of foods can be retarded in several ways, such as conditions of vacuum, or air replaced by nitrogen or low temperature. In industrial processing, addition of highly effective antioxidants has become a popular and highly effective means to lengthen the shelf life of foods and to reduce nutritional losses and harmful substances formed (Kanner et al., 1991; Tsuda et al., 1994).

Synthetic antioxidants, such as butylated hydroxyanisole (BHA), butylated hydroxytoluen (BHT) and tertbutylhydro-quinone (TBHQ), are widely used in the food

*Corresponding author: Mooha Lee, Department of Food and Animal Biotechnology, Research Institute for Agriculture and Life Science, Seoul National University, Seoul 151-921, Korea. Tel: 822-880-4820, Fax: 82-2-873-4804, E-mail: moohalee@snu.ac.kr industry. However, animal test have demonstrated that BHA and BHT accumulate in the body and result in liver damage and carcinogenesis (Ames, 1983; Baardseth, 1989; Grice, 1986; Ito et al., 1983; Ito et al., 1986; Wichi, 1988). Therefore, development and utilization of more effective and non-toxic antioxidants of natural origin are desired (Namiki, 1990).

Medicinal plants had traditionally played a major role in the management of human health and are still playing an active role in the health care in many countries. Particularly, digestive medicinal plants pharmacologically stimulate the exercise of stomach and secretion of digestive juice which helping digestion and absorption. Furthermore, they contain essential oils abundantly which have various biological activities. Most of antioxidant potentials in medicinal plants are due to the redox properties of phenolic compounds that allow them to act as reducing agents, hydrogen donators and free radicals quenchers (Shagidi and Wanasundara, 1992). A great number of natural medicinal plants have been tested for their antioxidant activities and results have shown that raw extracts or isolated pure compounds from them were more effective 
antioxidants in vitro than BHT or vitamin $\mathrm{E}$ (Gordon and Weng, 1992; Gu and Weng, 2001; Pyo et al., 2004). However, there were few reports about the application of medicinal plants extracts directly in foods, especially muscle originated foods.

So, this study was performed to examine the possibility of water extracts of several digestive medicinal plants, such as Amomum tasoko, Alpinia oxyphylla, Citrus unshiu, and Myristica fragrans, as a natural antioxidant. In this study we examined total phenol contents and inhibitory rate against linoleic acid peroxidation of selected digestive medicinal plant extracts (DMPEs) and we manufactured pork patties containing medicinal plant extracts, and then determined the shelf-life of those patties during cold storage.

\section{Material and Methods}

\section{Materials}

Dried Alpinia oxyphylla MIQ, Amomum tasoko CREVOST et LEM, Citrus unshiu MARCOR, and Myristica fragrans HOUTT were purchased from domestic oriental medicine clinic. Folin-Ciocalteau's phenol reagent, gallic acid, and thiobarbituric acid (TBA) were purchased from Sigma Chemical Co. (USA). All other chemicals and solvents used were analytical grade.

\section{Preparation of extracts from digestive medicinal plants}

Medicinal plants were extracted with 10 folds of distilled water in water bath (JEIO TECH CW-30G, Korea) at $100^{\circ} \mathrm{C}$ for $1 \mathrm{~h}$, subsequently filtered with Wattman No.1 filterpaper and lyophilized (Ilshin FD8505, Korea).

\section{Total phenol contents and antioxidative effect on linoleic acid emulsion peroxidation of extracts}

The Folin-Ciocalteu method was used (Javanmardi et al., 2003) and 1\% concentration of each DMPE solution in DW was made to measure total phenol contents of the extracts. The aliquots $(200 \mu \mathrm{L})$ of each extract were added to the test-tubes containing $1.0 \mathrm{~mL}$ of Folin-Ciocaltue's reagent and $800 \mu \mathrm{L}$ of $7.5 \%$ sodium carbonate followed by voltexing. The absorption at $765 \mathrm{~nm}$ was measured by spectrophotometer (X-ma 1000, Human co., Korea) after standing for $30 \mathrm{~min}$. The total phenol content was expressed as gallic acid equivalents (GAE) by reference to the gallic acid standard calibration curve.

Modified method of ferrithiocyanate of Haraguchi et al. (1992) was used to measure the antioxidative effect on linoleic acid emulsion peroxidation. $30 \mu \mathrm{L}$ of the extract solutions of all medicinal plant extracts in concentrations of $25 \mu \mathrm{g} / \mathrm{mL}$ was mixed with $400 \mu \mathrm{L}$ of $0.04 \mathrm{M}$ phosphate buffer and $200 \mu \mathrm{L}$ of $2.51 \%$ linoleic acid dissolved in ethanol. The reaction mixture was incubated at 37 for $60 \mathrm{~min}$. Thereafter, $100 \mu \mathrm{L}$ of reaction mixture was mixed with $2,700 \mu \mathrm{L}$ of $75 \%$ ethanol and $100 \mu \mathrm{L}$ of $30 \%$ ammonium thiocyanate. Subsequently $100 \mu \mathrm{L}$ of $0.02 \mathrm{M}$ ferrous chloride dissolved in $3.5 \% \mathrm{HCl}$ was added and after $3 \mathrm{~min}$ the absorbance was read at $500 \mathrm{~nm}$ and the percentage of linoleic acid peroxidation inhibition was calculated. BHA and $0.04 \mathrm{M}$ phosphate buffer were used as positive and negative control, respectively.

\section{Effects of DMPEs on shelf-life of pork patties}

Patties were prepared with trimmed pork ham grounded by $6 \mathrm{~mm}$ chopper plate. No additives were used to avoid interference with antioxidative activity. DMPEs were added to $100 \mathrm{~g}$ of patties at the level of $0.1,0.3$ or $0.5 \%$ before molding and then cooked by $80^{\circ} \mathrm{C}$-water bath (JEIO TECH CW-30G, Korea) for $30 \mathrm{~min}$. After cooling, patties were packed in LDPE bags and stored at $5^{\circ} \mathrm{C}$ refrigerator for $7 \mathrm{~d}$. $\mathrm{pH}$, TBARS and total microbes were measured at $0,1,4$, and $7 \mathrm{~d}$ of storage. $\mathrm{pH}$ of cooked patties was determined with digital $\mathrm{pH}$ meter (4 Star, Orion, USA) equipped with a combined glass electrode. On $5 \mathrm{~g}$ of patty was homogenized with $20 \mathrm{~mL}$ distilled water using Ultra-Turrex T25 tissue homogenizer (Janke and Kenkel, IKA, Labor Tecnik, Germany) for $1 \mathrm{~min}$. TBARS was analyzed by method of Witt et al. (1970) with slight modification and measured at $531 \mathrm{~nm}$ using spectrophotometer (X-ma 1000, Human Co., Korea). 5 g of patty was homogenized with $45 \mathrm{~mL}$ of buffered peptone water and serially diluted. Pour plate methods in duplicate were used to analyze the total microbes of patties. All experiments were repeated three times.

\section{Statistical analysis}

Statistical analysis was performed with the SAS program for Windows V9.1 (SAS Institute, USA). ANOVA with Duncan's multiple range test was carried out to analyze the significant differences among the treatments $(p<0.05)$.

\section{Results and Discussion}

\section{Total phenol contents of DMPEs}

The total phenol content of each DMPE was estimated, since phenolics may significantly contribute to its overall antioxidant activity. The total phenolic amounts of DMPEs 


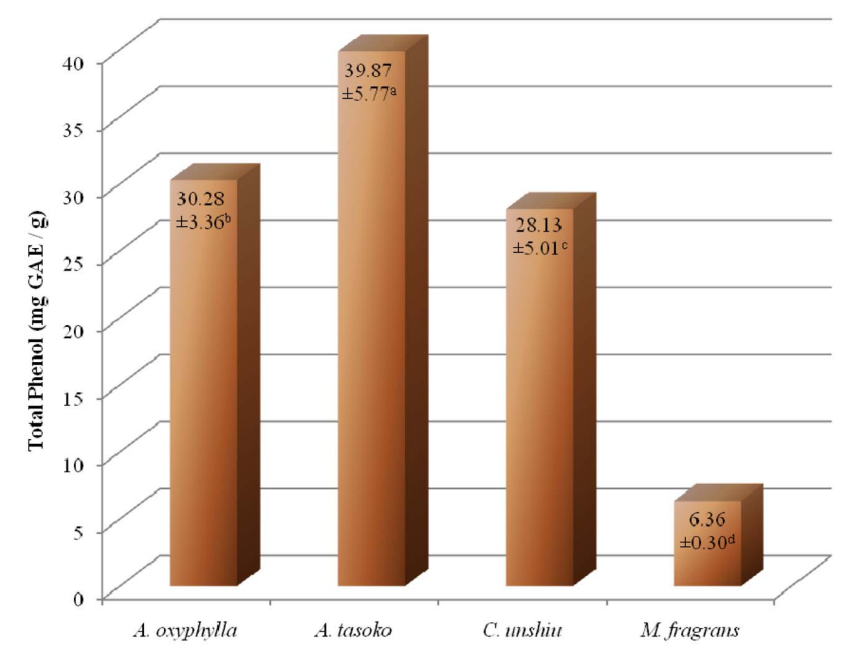

Fig. 1. Total phenol contents of medicinal plant extracts. $A$. oxyphylla, extract of $A$. oxyphylla; A. tasoko, extract of $A$. tasoko; C. unshiu, extract of C. unshiu; M. fragrans, extract of M. fragrans.

were significantly different among $A$. tasoko $(39.87 \pm 5.77 \mathrm{mg}$ GAE/g), A. oxyphylla (30.28 $\pm 3.36 \mathrm{mg} \mathrm{GAE} / \mathrm{g})$, C. unshiu $(28.13 \pm 5.01 \mathrm{mg} \mathrm{GAE} / \mathrm{g})$ and $M$. fragrans $(6.36 \pm 0.30 \mathrm{mg}$ GAE/g) $(p<0.05)$ (Fig. 1).

Wong et al. (2006) reported the total phenol content of A. oxyphylla using boiling water extracts and $80 \%$ methanol extracts was $3.97 \pm 0.12$ and $3.94 \pm 0.04 \mathrm{mg} \mathrm{GAE} / \mathrm{g}$, respectively, and in this study, A. oxyphylla extract showed 7 times higher amount of phenol, and it might be due to the different extraction method. Yoo et al. (2005) reported that total phenol contents of tangerine peel $(C$. unshiu) tea were $16.0,18.9$, and $20.9 \mathrm{mg} \%$ at 60,80 and 100 water extracts, respectively. Son et al. (2007) reported the total phenol contents of water, ethanol extract and essential oil of nutmeg (M. fragrans) were 3.4, 16.9, and $3.2 \mathrm{mg} \%$, respectively. And $\mathrm{Su}$ et al. (2007) also reported the total phenol content of nutmeg ( $M$. fragrans) using 50\% acetone and $80 \%$ methanol were $2.62 \pm 0.01$ and $2.68 \pm 0.12 \mathrm{mg} \mathrm{GAE} /$ g, respectively. In this study, compared with previous reports, there are similar or higher amount of total phenol content in DMPEs.

\section{Antioxidative effect on linoleic acid peroxidation of DMPEs}

The inhibitory activities of DMPEs on linoleic acid emulsion peroxidation were similar or significantly higher than that of BHA at 24, 48, and $72 \mathrm{~h}$ after reaction except extracts of C. unshiu (Table 1). Though there was low total phenol content in extract of $M$. fragrans, it showed highest antioxidative activity of $66.77 \pm 13.94 \%$ at $48 \mathrm{~h}$ after reaction. Furthermore, the extracts of A. tasoko showed significantly higher antioxidative effect at $72 \mathrm{~h}$ after reaction $(52.87 \pm 8.48 \%)$ than that of BHA (30.24 $11.75 \%)(p<0.05)$. Inhibitory activities of medicinal plant extracts were impressively increased at $24 \mathrm{~h}$ of reaction and decreased at $72 \mathrm{~h}$ of reaction.

Previous studies have found high significance, positive correlation between antioxidant capacity and phenolic content, indicating that phenolic compounds are a major contributor to antioxidant activity in the medicinal plants, herbs, vegetables and fruits (Velioglu et al., 1998, Cai et al., 2004; Dorman et al., 2004; Surveswaran et al., 2007). In contrast to those previous studies, the result of this study demonstrated that $C$. unshiu showed low antioxidative effect even though it has high phenol content, and $M$. fragrans showed high antioxidative effect although it has low phenol content.

\section{Change of $\mathrm{pH}$ values of pork patties during cold storage}

The $\mathrm{pH}$ values of $A$. tasoko, A. oxyphylla, C. unshiu and $M$. fragrans extract was $5.25 \pm 0.01,5.12 \pm 0.02,4.72 \pm$ 0.01 , and $5.39 \pm 0.08$, respectively (data not shown), and the effect of the addition of DMPEs on the $\mathrm{pH}$ value of pork patties held under chilled conditions is shown in Table 2. The $\mathrm{pH}$ values of several patties, such as patties treated with $M$. fragrans extract (FP) $0.1 \%$, patties treated

Table 1. Antioxidative effect of medicinal plant extracts on linoleic acid peroxidation

(Inhibition rate, \%)

\begin{tabular}{lcccc}
\hline \hline & \multicolumn{4}{c}{ Reaction time (h) } \\
\cline { 2 - 5 } & 0 & 24 & 48 & 72 \\
\hline A. oxyphylla & $5.56 \pm 3.41^{\mathrm{abC}}$ & $61.08 \pm 16.11^{\mathrm{A}}$ & $64.04 \pm 15.23^{\mathrm{aA}}$ & $39.25 \pm 12.75^{\mathrm{abB}}$ \\
A. tasoko & $10.50 \pm 0.78^{\mathrm{aB}}$ & $61.75 \pm 17.11^{\mathrm{A}}$ & $64.46 \pm 14.03^{\mathrm{aA}}$ & $52.87 \pm 8.48^{\mathrm{aA}}$ \\
C. unshiu & $0.25 \pm 9.74^{\mathrm{bB}}$ & $43.60 \pm 29.08^{\mathrm{A}}$ & $35.15 \pm 30.22^{\mathrm{bA}}$ & $11.59 \pm 32.23^{\mathrm{cAB}}$ \\
M. fragrans & $4.80 \pm 6.38^{\mathrm{abC}}$ & $60.47 \pm 14.90^{\mathrm{AB}}$ & $66.77 \pm 13.94^{\mathrm{aA}}$ & $50.55 \pm 4.05^{\mathrm{ab} A \mathrm{~B}}$ \\
BHA & $-6.97 \pm 2.75^{\mathrm{cC}}$ & $64.26 \pm 11.06^{\mathrm{A}}$ & $56.41 \pm 21.96^{\mathrm{abA}}$ & $30.24 \pm 11.75^{\mathrm{bB}}$ \\
\hline
\end{tabular}

Values are Mean \pm SD.

${ }^{\mathrm{a}-\mathrm{c}}$ Means in the same column with different letters are significantly different $(p<0.05)$.

${ }^{\mathrm{A}-\mathrm{C}}$ Means in the same row with different letters are significantly different $(p<0.05)$. 
Table 2. Change of $\mathrm{pH}$ of pork patties treated with various medicinal plant extracts during cold storage

\begin{tabular}{|c|c|c|c|c|c|}
\hline \multicolumn{2}{|c|}{$\%$} & \multicolumn{4}{|c|}{ S Storage time (d) } \\
\hline & & 0 & 1 & 4 & 7 \\
\hline \multirow{3}{*}{ FP } & 0.1 & $6.09 \pm 0.10^{\mathrm{abB}}$ & $6.13 \pm 0.08^{\mathrm{AB}}$ & $6.19 \pm 0.15^{\mathrm{aAB}}$ & $6.23 \pm 0.13^{\mathrm{A}}$ \\
\hline & 0.3 & $6.07 \pm 0.09^{\mathrm{ab}}$ & $6.12 \pm 0.03$ & $6.20 \pm 0.17^{\mathrm{a}}$ & $6.22 \pm 0.17$ \\
\hline & 0.5 & $6.08 \pm 0.12^{\mathrm{ab}}$ & $6.13 \pm 0.19$ & $6.20 \pm 0.15^{\mathrm{a}}$ & $6.25 \pm 0.20$ \\
\hline \multirow{3}{*}{$\mathrm{OP}$} & 0.1 & $6.04 \pm 0.06^{\mathrm{b}}$ & $6.12 \pm 0.02$ & $6.15 \pm 0.16^{\mathrm{a}}$ & $6.15 \pm 0.16$ \\
\hline & 0.3 & $6.06 \pm 0.04^{\mathrm{b}}$ & $6.08 \pm 0.05$ & $6.17 \pm 0.14^{\mathrm{a}}$ & $6.17 \pm 0.17$ \\
\hline & 0.5 & $6.04 \pm 0.05^{\mathrm{bB}}$ & $6.09 \pm 0.03^{\mathrm{AB}}$ & $6.18 \pm 0.12^{\mathrm{aA}}$ & $6.18 \pm 0.14^{\mathrm{A}}$ \\
\hline \multirow{3}{*}{$\mathrm{TP}$} & 0.1 & $6.14 \pm 0.13^{\mathrm{ab}}$ & $6.10 \pm 0.04$ & $6.16 \pm 0.14^{\mathrm{a}}$ & $6.18 \pm 0.13$ \\
\hline & 0.3 & $6.10 \pm 0.11^{\mathrm{ab}}$ & $6.09 \pm 0.08$ & $6.22 \pm 0.17^{\mathrm{a}}$ & $6.23 \pm 0.21$ \\
\hline & 0.5 & $6.07 \pm 0.06^{\mathrm{ab}}$ & $6.10 \pm 0.06$ & $6.18 \pm 0.16^{\mathrm{a}}$ & $6.18 \pm 0.17$ \\
\hline \multirow{3}{*}{ UP } & 0.1 & $6.18 \pm 0.12^{\mathrm{a}}$ & $6.18 \pm 0.10$ & $6.27 \pm 0.10^{\mathrm{a}}$ & $6.27 \pm 0.12$ \\
\hline & 0.3 & $6.13 \pm 0.10^{\mathrm{abB}}$ & $6.15 \pm 0.13^{\mathrm{B}}$ & $6.28 \pm 0.11^{\mathrm{aA}}$ & $6.28 \pm 0.12^{\mathrm{A}}$ \\
\hline & 0.5 & $6.09 \pm 0.07^{\mathrm{abB}}$ & $6.13 \pm 0.09^{\mathrm{B}}$ & $6.24 \pm 0.13^{\mathrm{aA}}$ & $6.25 \pm 0.10^{\mathrm{A}}$ \\
\hline \multirow{3}{*}{ BP } & 0.1 & $6.13 \pm 0.12^{\mathrm{ab}}$ & $6.14 \pm 0.15$ & $6.17 \pm 0.14^{\mathrm{a}}$ & $6.23 \pm 0.17$ \\
\hline & 0.3 & $6.07 \pm 0.08^{\mathrm{abB}}$ & $6.15 \pm 0.11^{\mathrm{AB}}$ & $6.21 \pm 0.10^{\mathrm{aA}}$ & $6.19 \pm 0.19^{\mathrm{AB}}$ \\
\hline & 0.5 & $6.13 \pm 0.14^{\mathrm{ab}}$ & $6.15 \pm 0.14$ & $6.21 \pm 0.16^{\mathrm{a}}$ & $6.25 \pm 0.19$ \\
\hline $\mathrm{CP}$ & & $6.07 \pm 0.09^{\mathrm{abAB}}$ & $6.09 \pm 0.13^{\mathrm{AB}}$ & $6.00 \pm 0.21^{\mathrm{bB}}$ & $6.20 \pm 0.16^{\mathrm{A}}$ \\
\hline
\end{tabular}

Values are mean \pm SD.

FP, Patties treated with M. fragrans extract; OP, Patties treated with A. oxyphylla extract; TP, Patties treated with A. tasoko extract; UP, Patties treated with C. unshiu extract; BP, Patties treated with BHA; CP, Control patties.

${ }^{a, b}$ Means in the same column with different letters are significantly different $(p<0.05)$.

${ }^{\mathrm{A}, \mathrm{B}}$ Means in the same row with different letters are significantly different $(p<0.05)$.

with A. oxyphylla extract (OP) $0.5 \%$, patties treated with C. unshiu extract (UP) 0.3 and $0.5 \%$, patties treated with BHA (BP) $0.3 \%$ and control patties (CP), increased significantly during storage period $(p<0.05)$. The increase in $\mathrm{pH}$ is due to the accumulation of metabolites by bacterial action in meat and deaminations of proteins (Jay, 1996). The $\mathrm{pH}$ values of patties incorporated with $A$. oxyphylla (OP) were significantly lower than others at day 0 $(p<0.05)$, and the $\mathrm{pH}$ values of all tested patties were significantly higher than that of control patty at $4 \mathrm{~d}$ of storage $(p<0.05)$. However, the concentration and the species of medicinal plant extract did not affect consistently the $\mathrm{pH}$ values of patties overall storage period, and it might be caused by the amount of added extracts was not enough to bring differences between the concentration and the species.

Mansour and Khalil (2000) reported that there was no difference in $\mathrm{pH}$ between controls and antioxidants added samples over $35 \mathrm{~d}$ of chilled storage, however, the $\mathrm{pH}$ values of all patties increased significantly during storage. McCarthy et al. (2001) and Sahoo (1995) reported similar findings in pork patties and in ground buffalo meat containing BHA/BHT antioxidants during refrigerated and frozen storage, respectively. In our study, the difference between control and treatments was might be caused by the low $\mathrm{pH}$ of added DMPEs.

\section{TBARS of pork patties with DMPEs}

The chemical analysis of TBARS is widely used as indicator of lipid oxidation in meat studies and it has repeatedly been demonstrated the relationship of sensory terms versus log TBARS (Nissen et al., 2000; Poste et al., 1986; Stapelfeldt et al., 1992).

The effect of the addition of DMPEs on TBARS development during refrigerated storage of cooked pork patties is shown in Table 3. In general, the TBARS values of all patties were increased significantly during chilled storage $(p<0.05)$. However, the TBARS values of patties with DMPEs (except UP) were significantly lower than that of control patty at $7 \mathrm{~d}$ of storage, and as the amount of added extract increased, such tendency was distinct. The TBARS values of patties with TP were lower than others, and those of patties with OP, FP and UP were in the increasing order. Especially, patties with $0.5 \% \mathrm{~A}$. tasoko extract (TP $0.5 \%$ ) showed no significant difference from the patties with $0.5 \%$ of BHA (BP $0.5 \%$ ) at $7 \mathrm{~d}$ of storage $(p>0.05)$. However, in contrast with the strong inhibition on linoleic acid peroxidation, the extract of $M$. fragrans did not showed strong inhibition activity on lipid oxidation in pork patty. Patties with $C$. unshiu extract did not show significant difference with control patties $(p>0.05)$ and that coincide with the previous result of antioxidative effect on linoleic acid peroxidation which showed the 
Table 3. Change of TBARS (mg malonaldehyde/kg) of pork patties treated with medicinal plant extracts during cold storage

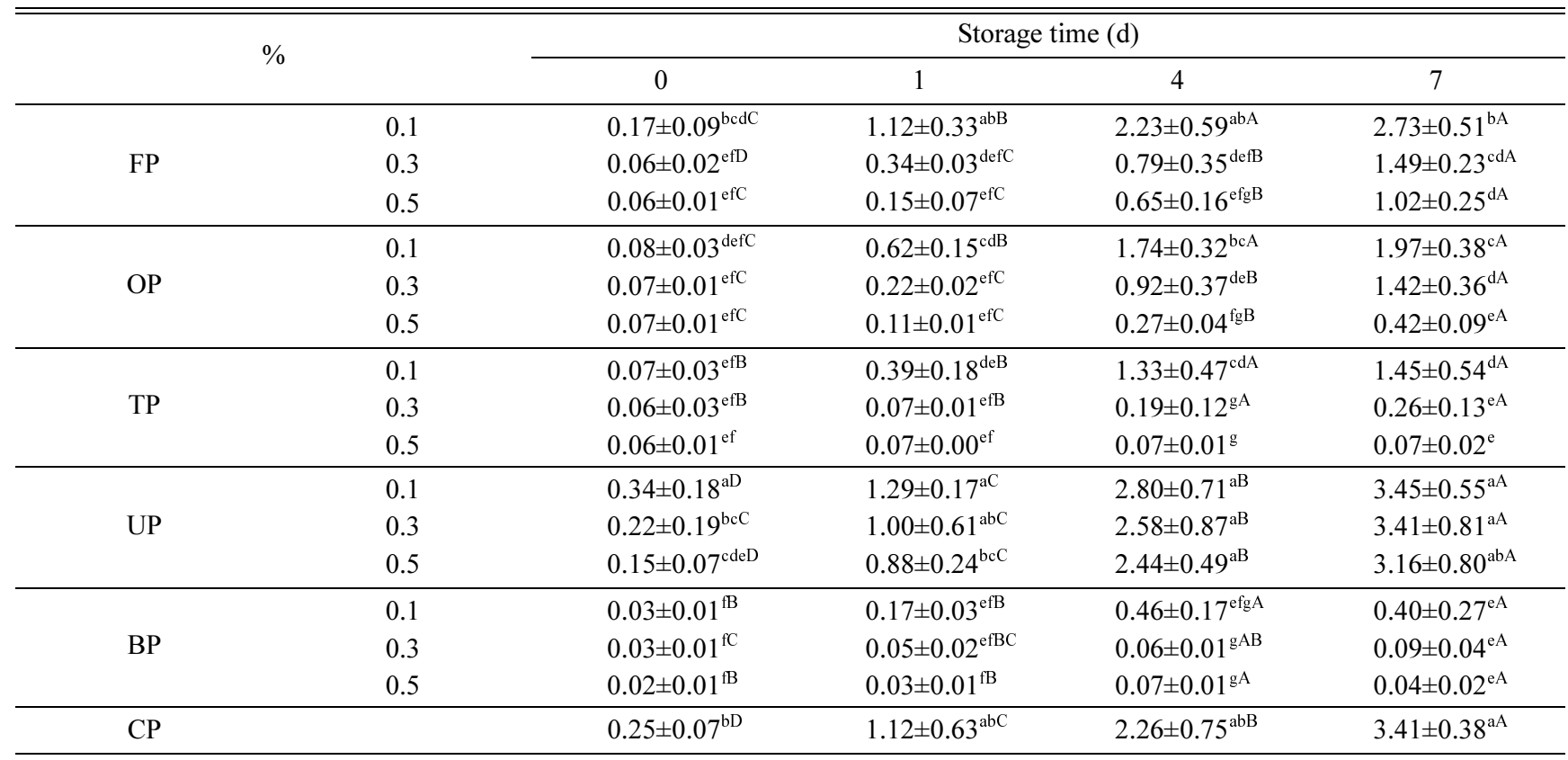

Values are mean \pm SD.

FP, Patties treated with M. fragrans extract; OP, Patties treated with A. oxyphylla extract; TP, Patties treated with A. tasoko extract; UP, Patties treated with $C$. unshiu extract; BP, Patties treated with BHA; CP, Control patties.

${ }^{\mathrm{a}-\mathrm{g}}$ Means in the same column with different letters are significantly different $(p<0.05)$.

${ }^{\mathrm{A}-\mathrm{D}}$ Means in the same row with different letters are significantly different $(p<0.05)$.

lowest effect, however, that does not coincide with the previous study of Min et al. (2002) which showed high (80.93-83.27\%) electron donating abilities. These results coincide with the report of Park et al. (2005) that the TBARS of marinated beef incorporated with medicinal plant mixture extract such as S. miltiorrhiza, G. uralensis, $S$. chinesis Bacillon, C. sappan L., and L. erythrorhizon was lower increase rate than that of control beef, and as the amount of added extract increased that tendency was distinct.

Hernández-Hernández et al. (2009) reported rosemary extract added raw pork batter showed the lowest TBARS. Nissen et al. (2004) reported that rosemary, green tea and grape skin extracts showed significantly low TBARS in chilled-stored precooked pork patties and Rey et al. (2005) reported that cloudberry extract and quercetin showed most effective in preventing lipid oxidation in cooked pork patties after $3 \mathrm{~d}$ of refrigerated storage.

Phenols stabilized hydroperoxides preventing further degradation to more active oxidizing forms, such as malonaldehyde (Wellwood and Cole, 2004). Phenol compounds complex with $\mathrm{Fe}^{2+}$ preventing hydroxyl radical formation. According to other authors (Frankel and Huang, 1996; Frankel et al., 1994) the antioxidant effect of carnosic acid is due to its lipophilic characteristics. Kilic and
Richards (2003) reported that lipid oxidation in an oil-inwater emulsion increases with decreasing antioxidant polarity; antioxidant compounds were located at the interface where hydroperoxides were in contact with prooxidants.

\section{Change of total microbes of pork patties with DMPEs}

The effect of the addition of DMPEs on total microbes during chilled storage of cooked pork patties is shown in Table 4. In general, patties significantly increased in total plate counts (TPC) as the storage period increased. Park et al. (2005) reported that the addition of medicinal plant mixture extract to marinated beef inhibited the microbial growth during chilled storage. Mansour and Khalil (2000) reported that beef patties without antioxidant increased in TPC at the 28th in chilled and 45th day in frozen samples, and this might be due to cooking which drastically injured and/or killed the microbial population (Jay, 1996). However, in this study, at $7 \mathrm{~d}$ of storage, there was no significant difference between medicinal plant extract treated and control patties $(p>0.05)$.

Though extracts from tested digestive medicinal plants did not show significant antimicrobial effect, extract of A. tasoko showed as strong antioxidative effect as chemical 
Table 4. Change of total microbes $(\log \mathrm{CFU} / \mathrm{g})$ of pork patties treated with medicinal plant extracts during cold storage

\begin{tabular}{|c|c|c|c|c|c|}
\hline & \multirow{2}{*}{$\%$} & \multicolumn{4}{|c|}{ Storage time (d) } \\
\hline & & 0 & 1 & 4 & 7 \\
\hline \multirow{3}{*}{ FP } & 0.1 & $2.05 \pm 0.77^{\mathrm{abcB}}$ & $1.26 \pm 0.35^{\mathrm{C}}$ & $2.05 \pm 0.67^{\mathrm{abAB}}$ & $4.12 \pm 0.86^{\mathrm{A}}$ \\
\hline & 0.3 & $1.87 \pm 0.44^{\mathrm{abcdB}}$ & $1.87 \pm 0.41^{\mathrm{B}}$ & $1.86 \pm 0.31^{\mathrm{bB}}$ & $3.20 \pm 1.65^{\mathrm{A}}$ \\
\hline & 0.5 & $1.80 \pm 0.45^{\mathrm{abcdB}}$ & $1.93 \pm 0.44^{\mathrm{B}}$ & $2.69 \pm 0.90^{\mathrm{abA}}$ & $2.86 \pm 0.92^{\mathrm{B}}$ \\
\hline \multirow{3}{*}{$\mathrm{OP}$} & 0.1 & $1.70 \pm 0.55^{\mathrm{abcdB}}$ & $1.98 \pm 0.31^{\mathrm{B}}$ & $2.50 \pm 0.95^{\mathrm{abB}}$ & $3.40 \pm 1.32^{\mathrm{A}}$ \\
\hline & 0.3 & $1.64 \pm 0.61^{\mathrm{bcdeB}}$ & $2.03 \pm 0.35^{\mathrm{B}}$ & $2.10 \pm 1.01^{\mathrm{abB}}$ & $2.92 \pm 0.79^{\mathrm{A}}$ \\
\hline & 0.5 & $2.21 \pm 0.72^{\mathrm{ab}}$ & $2.16 \pm 0.62$ & $2.37 \pm 0.47^{\mathrm{ab}}$ & $2.74 \pm 0.71$ \\
\hline \multirow{3}{*}{$\mathrm{TP}$} & 0.1 & $1.88 \pm 0.43^{\mathrm{abcdB}}$ & $2.19 \pm 0.26^{\mathrm{B}}$ & $2.27 \pm 0.39^{\mathrm{abB}}$ & $3.20 \pm 1.52^{\mathrm{A}}$ \\
\hline & 0.3 & $1.79 \pm 0.18^{\mathrm{abcdC}}$ & $1.93 \pm 0.46^{\mathrm{C}}$ & $2.75 \pm 0.28^{\mathrm{abB}}$ & $3.38 \pm 0.86^{\mathrm{A}}$ \\
\hline & 0.5 & $2.29 \pm 0.53^{\mathrm{aB}}$ & $2.04 \pm 0.39^{\mathrm{AB}}$ & $2.42 \pm 0.89^{\mathrm{abAB}}$ & $3.23 \pm 1.45^{\mathrm{A}}$ \\
\hline \multirow{3}{*}{ UP } & 0.1 & $1.87 \pm 0.60^{\mathrm{abcdC}}$ & $2.26 \pm 0.83^{\mathrm{BC}}$ & $2.85 \pm 0.52^{\mathrm{aAB}}$ & $3.23 \pm 0.07^{\mathrm{A}}$ \\
\hline & 0.3 & $1.92 \pm 0.50^{\mathrm{abcdB}}$ & $1.92 \pm 0.78^{\mathrm{B}}$ & $2.98 \pm 0.58^{\mathrm{aA}}$ & $3.23 \pm 0.68^{\mathrm{A}}$ \\
\hline & 0.5 & $1.48 \pm 0.59^{\text {cdeC }}$ & $2.01 \pm 0.33^{\mathrm{BC}}$ & $2.79 \pm 1.13^{\mathrm{abAB}}$ & $3.03 \pm 0.21^{\mathrm{A}}$ \\
\hline \multirow{3}{*}{$\mathrm{BP}$} & 0.1 & $1.13 \pm 0.16^{\mathrm{eC}}$ & $1.97 \pm 0.35^{\mathrm{B}}$ & $2.53 \pm 0.71^{\mathrm{abAB}}$ & $2.91 \pm 0.64^{\mathrm{A}}$ \\
\hline & 0.3 & $1.77 \pm 0.57^{\mathrm{abcdB}}$ & $1.75 \pm 0.39^{\mathrm{B}}$ & $2.50 \pm 1.00^{\mathrm{ab} A \mathrm{~B}}$ & $2.71 \pm 0.28^{\mathrm{A}}$ \\
\hline & 0.5 & $2.25 \pm 0.36^{\mathrm{aB}}$ & $1.73 \pm 0.40^{\mathrm{C}}$ & $2.31 \pm 0.41^{\mathrm{abB}}$ & $3.29 \pm 0.51^{\mathrm{A}}$ \\
\hline $\mathrm{CP}$ & & $1.39 \pm 0.37^{\mathrm{deB}}$ & $2.07 \pm 0.43^{\mathrm{B}}$ & $2.77 \pm 0.72^{\mathrm{abA}}$ & $3.27 \pm 0.98^{\mathrm{A}}$ \\
\hline
\end{tabular}

Values are mean $\pm \mathrm{SD}$.

FP, Patties treated with M. fragrans extract; OP, Patties treated with $A$. oxyphylla extract; TP, Patties treated with $A$. tasoko extract; UP, Patties treated with C. unshiu extract; BP, Patties treated with BHA; CP, Control patties.

${ }^{a-e}$ Means in the same column with different letters are significantly different $(p<0.05)$.

${ }^{\mathrm{A}-\mathrm{C}}$ Means in the same row with different letters are significantly different $(p<0.05)$.

antioxidant, BHA.

Digestive medicinal plant extracts tested in this study were containing sufficient phenolic compounds to inhibit linoleic acid peroxidation and lipid oxidation in cooked pork patties during cold storage. Therefore, there is possibility to develop the natural antioxidant with those medicinal plants as an alternative of synthetic antioxidants, and need to study more about the functionality of phytochemicals derived from various kinds of medicinal plants and herbs.

\section{References}

1. Ames, B. M. (1983) Dietary carcinogens and anticarcinogens: oxygen radical and degenerative diseases. Science 221, 1256-1264.

2. Baardseth, P. (1989) Effect of selected antioxidants on the stability of dehydrated mashed potatoes. Food Add. Contam. 6, 201-207.

3. Cai, Y. Z., Luo, Q., Sun, M., and Corke, H. (2004) Antioxidant activity and phenolic compounds of 112 Chinese medicinal plants associated with anticancer. Life Sci. 74, 21572184.

4. Dorman, H. J., Bachmayer, O., Kosar, M., and Hiltunen, R. (2004) Antioxidant properties of aqueous extracts from selected Lamiaceae species grown in Turkey. J. Agr. Food
Chem. 52, 762-770.

5. Edwin, N. (1996) Antioxidants in lipid foods and their impact on food quality. Food Chem. 57, 51-55.

6. Frankel, E. N. and Huang, S. W. (1996) Evaluation of antioxidant activity or rosemary extracts carnosol and carnosic acid in bulk vegetable oils and fish oil and their emulsion. J. Sci. Food Agric. 72, 201-208.

7. Frankel, E. N., Huang, S. W., Kanner, J., and German, J. B. (1994) Interfacial phenomena in the evaluation of antioxidants: Bulk oils vs. emulsions. J. Agr. Food Chem. 42, 10541059.

8. Gordon, M. H. and Weng, X. C. (1992) Antioxidant properties of extracts from tanshen (Salvia miltiorrhiza Bunge). Food Chem. 44, 119-122.

9. Grice, H. C. (1986) Safety evaluation of butylated hydroxytoluene (BHT) in the liver, lung and gastrointestinal tract. Food Chem. Toxicol. 24, 1127-1130.

10. Gu, L. W. and Weng, X. C. (2001) Antioxidant activity and components of Salvia plebeian R. Br. - a Chinese herb. Food Chem. 73, 299-305.

11. Haraguchi, H., Hashimoto, K., and Yagi, A. (1992) Antioxidative substances in leaves of Polygonum hydropiper. J. Agr. Food Chem. 40, 1349-1351.

12. Hernández-Hernández, E., Ponce-Alquicira, E., JaramilloFlores, M. E., and Guerrero Legarreta, I. (2009) Antioxidant effect rosemary (Rosmarinus officinalis L.) and oregano (Origanum vulgare L.) extracts on TBARS and colour of model raw pork batters. Meat Sci. 81, 410-417.

13. Ito, N., Fukushima, S., Hasegawa, A., Shibata, M., and 
Ogiso, T. (1983) Carcinogenicity of butylated hydroxyanisole in F344 rats. J. Natl. Cancer Ins. 70, 343-347.

14. Ito, N., Hirose, M., Fukushima, S., Tsuda, H., Shirai, T., and Tatematsu, M. (1986) Studies on antioxidants: Their carcinogenic and modifying effects on chemical carcinogenesis. Food Chem. Toxicol. 24, 1099-1102.

15. Jay, J. M. (1996) Antioxidants. In: Modern food microbiology, 4th ed., India, CBS Publishers and Distributors, New Delhi, pp. 265-266.

16. Javanmardi, J., Stushnoff, C., Locke, E., and Vivanco, J. M. (2003) Antioxidant activity and total phenolic content of Iranian Ocimum accessions. Food Chem. 83, 547-550.

17. Kanner, J., Harel, S., and Jeffe, R. (1991) Lipid peroxidation of muscle food as affected by NaCl. J. Agr. Food Chem. 39, 1017-1021.

18. Kilic, B. and Richards, M. P. (2003) Lipid oxidation in poultry döner kebab: Pro-oxidative and anti-oxidative factors. $J$. Food Sci. 68, 686-689.

19. Mansour, E. H. and Khalil, A. H. (2000) Evaluation of antioxidant activity of some plant extracts and the application to ground beef patties. Food Chem. 69, 135-141.

20. McCarthy, T. L., Kerry, J. F., Lynch, P. B., and Buckley, D. J. (2001) Evaluation of antioxidant potential of natural foods plant extract as compared with synthetic antioxidants and vata-E in raw and cooked pork patties. Meat Sci. 57, 45-52.

21. Min, S. H., Park, H. O., and Oh, H. S. (2002) A study on the properties of hot water extracts of Koreasn dried tangerine peel and development of beverage by using it. Kor. J. Food Cookery Sci. 18, 51-56.

22. Namiki, M. (1990) Antioxidants/Antimutagens in Food. Cri. Rev. Food Sci. Nutr. 29, 273-300.

23. Nissen, L. R., Byrne, D. V., Bertelsen, G., and Skibsted, L. H. (2004) The antioxidative activity of plant extracts in cooked pork patties as evaluated by descriptive sensory profiling and chemical analysis. Meat Sci. 68, 485-495.

24. Nissen, L. R., Månsson, L., Bertelsen, G., Huynh-Ba, T., and Skibsted, L. H. (2000) Protection of dehydrated chicken meat by natural antioxidants as evaluated by electron spin resonance spectrometry. J. Agr. Food Chem. 48, 5548-5556.

25. Park, J. G., Her, J. H., Li, S. Y., Cho, S. H., Youn, S. K., Choi, J. S., Park, S. M., and Ahn, D. H. (2005) Study on the improvement of storage property and quality in the traditional seasoning beef containing medicinal plant herb extracts. J. Korean Soc. Food Sci. Nutr. 34, 113-119.

26. Poste, L. M., Willemot, C., Butler, G., and Patterson, C. (1986) Sensory aroma scores and TBA values as indices of warmed-over flavor in pork. J. Food Sci. 51, 886-888.

27. Pyo, Y. H., Lee, T. C., Logendrac, L., and Rosen, R. T. (2004) Antioxidant activity and phenolic compounds of Swiss chard (Beta vulgaris subspecies cycla) extracts. Food Chem. 85, 19-26.

28. Rey, A. I., Hopia, A., Kivikari, R., and Kahkonen, M. (2005)
Use of natural food/plant extract: cloudberry (Rubus Chamaemorus), beetroot (Beta Vulgaris "Vulgaris") or willow herb (Epilobium angustifolium) to reduce lipid oxidation of cooked pork patties. LWT-Food Sci. Technol. 38, 363-370.

29. Sahoo, J. (1995) Effect of preblending and vacuum packaging on the quality of ground buffalo meat. Ph.D. thesis, Deemed Univ., IVRI, Izatnagar, India.

30. Shahidi, F. and Wanasundara, P. K. (1992) Phenolic antioxidants. Crit. Rev. Food Sci. Nutr. 32, 67-103.

31. Son, J. Y., Heuing, B. J., Takeda, Y., and Ando, K. (2007) Functional properties of nutmeg. Korean J. Food Cookery Sci. 23, 33-40.

32. Stapelfeldt, H., Bjørn, H., Skovgaard, I. M., Skibsted, L. H., and Bertelsen, G. (1992) Warmed-over flavor in cooked sliced beef. Z. Lebensm. Unters. For. 195, 203-208.

33. Su, L., Yin, J. J., Charles, D., Zhou, K., Moore, J., and Yu, L. (2007) Total phenolic contents, chelating capacities, and radical-scabenging properties of black peppercorn, nutmeg, rosehip, cinnamon and oregano leaf. Food Chem. 100, 990997.

34. Surveswaran, S., Cai, Y. Z., Corke, H., and Sun, M. (2007) Systematic evaluation of natural phenolic antioxidants from 133 Indian medicinal plants. Food Chem. 102, 938-953.

35. Tsuda, T., Ohshima, K., Kawakishi, S., and Osawa, T. (1994) Antioxidative pigments isolated from the seeds of Phaseolus vulgaris L. J. Agr. Food Chem. 42, 248-251.

36. Velioglu, Y. S., Mazza, G., Gao, L., and Oomah, B. D. (1998) Antioxidant activity and total phenolics in selected fruits, vegerables, and grain products. J. Agr. Food Chem. 46, 41134117.

37. Wellwood, C. R. L. and Cole, R. A. (2004) Relevance of carnosic acid concentrations to the selection of rosemary, Rosmarinus officinalis (L.) accessions for optimization of antioxidant yield. J. Agr. Food Chem. 52, 6101-6107.

38. Wichi, H. P. (1988) Enhanced tumor development by butylated hydroxyanisole (BHA) from the perspective of effect on forestomach and oesophageal squamous epithelium. Food Chem. Toxicol. 26, 717-723.

39. Witt, V. C., Krouze, G. F., and Bailey, M. E. (1970) A new extraction method for determining 2-thiobarbituric acid values of pork and beef during storage. J. Food Sci. 35, 482485.

40. Wong, C. C., Li, H. B., Cheng, K. W., and Chen, F. (2006) A systematic survey of antioxidant activity of 30 Chinese medicinal plants using the ferric reducing antioxidant power assay. Food Chem. 97, 705-711.

41. Yoo, K. M., Kim, C. E., Kim, D. I., Huh, D., and Hwang, I. (2005) Antioxidant activity and physiocochemical characteristics of Tangerine peel tea prepared with Citrus unshiu cultivated in Cheju. Korean J. Food Cookery Sci. 21, 354-359.

(Received 2010.10.23/Revised 2010.12.27/Accepted 2011.1.9) 